\title{
O trabalho de leitura dialógico em uma transposição do texto verbal para um texto sincrético
}

\author{
Cristiane Passafaro Guzzi *
}

\begin{abstract}
Resumo: A possibilidade de um estudo pormenorizado sobre o processo criativo de uma minissérie televisiva, baseada na transposição de uma obra literária, nos instigou a querer compreender melhor as relações existentes entre Literatura e Cinema, Literatura e Televisão, especialmente após o trabalho realizado pelo diretor Luiz Fernando Carvalho, ao adaptar o romance Dom Casmurro (1899), de Machado de Assis, para a minissérie Capitu (2008). A compreensão que fazemos da leitura de Carvalho transparece nos ressoos figurativos que ele evidencia por intermédio dos procedimentos de citação, seja de forma direta, seja de forma indireta. Esse ressoo de traços de significação, que nos remetem aos diálogos com outros textos e com outras tradições, configuram-se desde a escolha do cenário, o posicionamento da iluminação, os efeitos de enquadramento da câmera, a caracterização e o vestuário das personagens, até a trilha sonora escolhida para embalar a trama, preenchendo e atualizando, assim, o texto de Dom Casmurro de novas visibilidade, diálogos e interpretações.
\end{abstract}

Palavras-chave: Transposição. Machado de Assis. Procedimentos discursivos de citação. Luiz Fernando Carvalho.

O texto verbal literário tem a especificidade de nos convocar, pela leitura, para um jogo sinestésico em que as correspondências visuais da própria encenação, auditivas, táteis, com manifestações de outros sentidos - paladar/olfato - emergem dos signos verbais em movimento, tecendo o fio em que se enredam essas sensações. Desse modo, a significação, a partir dos sentidos, vai se impondo no espaço entre obra e leitor, de tal forma que se esvaem os limites nessa interação.

$O$ ato de leitura de uma obra leva em conta a experiência sensível da linguagem e a experiência cultural de mundo daquele que faz reverberar seu ponto de vista no ato interpretativo. Levar isso em consideração, no caso específico do escritor Machado de Assis, é de extrema importância, uma vez que ele instaura um enunciador que prevê, a todo o momento de suas narrativas, um enunciatário que participe do ato de encenação da sua obra. O enunciador presente nas obras de Machado convoca e

\footnotetext{
* Doutoranda em Estudos Literários do Programa de Pós-Graduação em Estudos Literários. Bolsista CAPES/UNESP - Universidade Estadual Paulista. Faculdade de Ciências e Letras. Araraquara, SP, Brasil.
} 
dialoga com esse leitor que tem que se apresentar e vir a preencher certas sombras com que o texto trabalha e que vêm carregadas pela ideologia, pelo sujeito.

O romance Dom Casmurro (1899), como a literatura canônica em geral, instituise como uma obra que convoca leituras em continuidade, permitindo ao leitor que se proponha analisar os significados engendrados pelo texto, a partir da autonomia de seus significantes. Cada leitura da obra de Machado considera e redimensiona as leituras anteriores, construindo um paradigma crítico que aponta para novas possibilidades de leituras combinatórias. A minissérie televisiva Capitu (2008), escrita por Euclydes Marinho, com colaboração de Daniel Piza, Luís Alberto de Abreu e Edna Palatnik, e texto final do diretor Luiz Fernando Carvalho -, apresenta-se como uma transposição aproximada da obra Dom Casmurro.

Na leitura televisiva da obra machadiana, infere-se, desde logo, uma construção realizada mediante a troca enunciativa entre dois estilos diferentes, no caso, do escritor e do seu idealizador, os quais confluíram num trabalho outro. $O$ trabalho de Carvalho, desse modo, pode ser entendido como uma compreensão responsiva ativa conceito que o filósofo da linguagem, Mikhail Bakhtin, denomina como sendo a resposta de todo enunciado - tanto do percurso traçado pela história da crítica machadiana mais tradicional, quanto da convocação e mobilização de outras leituras atualizantes para um diálogo atemporal com a obra. Ao compor sua enunciação por uma retomada das diversas vozes que dialogam na construção de um paradigma de leitura já instituído sobre o romance Dom Casmurro, Carvalho fez com que o conceito de dialogismo, base dos estudos do Círculo de Bakhtin, se fizesse presente na minissérie. Tal presença se dá não só no que diz respeito ao modo de funcionamento real da linguagem, mas também como a própria forma composicional que configura Capitu.

Essa possibilidade do dialogismo ser entendido como um princípio composicional de incorporação, pelo enunciador, das vozes de outro(s) em seu próprio enunciado corrobora o movimento de construção evidenciado na aproximação de Carvalho. Sabemos, no entanto, que o dialogismo vai além de sua forma composicional, constituindo-se, fundamentalmente, como o princípio de funcionamento da linguagem em sua comunicação real e sendo o próprio modo de constituição de um enunciado. 0 modo como o discurso alheio é absorvido ou internalizado no próprio enunciado tornase uma maneira visível de se inferir as vozes dialógicas presentes no discurso transposto, tendo, ainda, como fundamento, a irrepetibilidade inerente aos enunciados, uma vez que estes se apresentam como acontecimentos únicos e possuem, portanto, um acento, uma apreciação, uma entonação própria.

Tais considerações nos levam a refletir também sobre o modo como a aproximação de uma obra, já tão consagrada pela crítica e pelo público de literatura em geral, apresenta certos valores, e certas interpretações que ressoam de modo consolidado na memória discursiva de seus leitores, de seus telespectadores. Esse fator faz com que se espere, de alguma forma, certa aproximação com tal paradigma estabelecido por um consenso de leitura. Dessa maneira, a enunciação de Capitu mostra-se permeada por um tom que parece ter ponderado e levado em consideração valores, discursos e vozes que não poderiam ficar ausentes na aproximação. Escolhas 
que são de responsabilidade de quem as seleciona e as organiza, e que já denunciam uma tomada de posição do enunciador que quer transpor, no tom escolhido, determinada homenagem e/ou respeito para com o material selecionado e transposto.

Há uma notável importância, na apreensão da significação, do peso, do valor e do tom que certas escolhas representam numa obra artística, como é o caso da exploração feita por escritores tais como Guimarães Rosa e João Gilberto Noll, só para citar alguns. Esses autores se destacam por uma entonação carregadamente expressiva na seleção e organização de significados devido às palavras minuciosamente pinçadas e, evidentemente, carregadas na exploração estética. Podemos incluir Luiz Fernando Carvalho como um desses autores que também partem da palavra, mas, no caso, para transformar em imagem - ao carregar no tom dado a esta - e explorar essa função autoral que lhe permite promover um espetáculo discursivo. Dessa forma, consequentemente, provoca e mobiliza eventos, na linguagem, como a exploração de intertextualidades, interdiscursividades, pastiches, paródias, porém no tom dado à configuração imagética.

Podemos pensar, nesse sentido, que os valores mobilizados por Carvalho ao entrar em diálogo com os valores presentes no romance de Machado - seja por intermédio de uma refutação, distorção, estilização, atualização, ou confirmação configuram-se como uma grade de leitura da própria obra machadiana, uma vez que a crítica tradicional e suas trajetórias atuais se fazem presentes nas estratégias enunciativas mobilizadas. Carvalho parece estabelecer, portanto, uma compreensão para com as reverberações de Machado, as quais se fazem cumpridas num outro tom, por sua vez, de homenagem na minissérie realizada. Tal senso ocorre também no que tange à sua tomada de posição em relação aos valores, transpostos para a televisão, de um romance com um percurso tão conturbado, pela presença de tão distintas vozes críticas, mas também tão aclamado em sua tradição de leitura.

Tendo em vista que este trabalho trata do modo como um realizador, no caso, um diretor específico, leu determinado romance para, então, trabalhar artisticamente o material a ser transposto, traçamos um percurso, também, enquanto leitores críticos desse processo que nos foi delineado em tela. Como um mosaico de vozes e leituras, nossa compreensão, da mesma forma, fez-se responsiva e crítica, na medida em que o texto, tanto o verbal quanto o sincrético, demandou determinadas leituras, excluiu tantas outras e, até mesmo, levou-nos a adentrar em horizontes antes nem pensados, como é próprio da concepção de toda obra artística.

A crítica, como um processo sintagmático que vai sendo enriquecido pelas leituras (convergentes ou divergentes) do tempo, cria uma espécie de diálogo interno entre os membros de uma comunidade que a interpreta. O termo "comunidade interpretativa", originado dos estudos literários, especificamente nas teorias da recepção, foi cunhado por Stanley Fish, em sua obra Is there a text in this class? The authority of interpretive communities (1980). Para o autor, dentro dessa comunidade, as perguntas e respostas são responsivas entre elas e essa propriedade dos enunciados ganha ênfase no interior das tais comunidades. Diante disso, o texto passa a significar tudo aquilo que a comunidade interpretativa quer ou entende que ele signifique. Seu significado é, desse modo, muitas vezes dissociado do texto em si, sendo atribuído à interpretação pelos leitores especializados englobados por este conjunto avaliativo que determina a forma como tal obra ou conceito deve ser lido. 
Nosso caminho, enquanto leitores de um trabalho que também se configura como resultado de práticas de leituras do diretor, aponta para uma compreensão da crítica que se faz, seletivamente, de acordo com outras leituras dirigidas sobre a crítica já cristalizada pela tradição. Faz-se notório destacar, contudo, que outro telespectador ou outro leitor, ao empreender uma leitura de entretenimento ou até mesmo outro percurso analítico de leitura da minissérie, não invalida nossa proposta (ainda que a possa questionar), pois estabelece um novo e outro contrato fiduciário coerente com seus horizontes de expectativa e, principalmente, de leitura.

\section{A presença de Dom Casmurro em Capitu: as reverberações de vozes pelos procedimentos discursivos de citação}

As experiências de Machado de Assis, enquanto poeta, crítico, contista, dramaturgo e romancista, parecem reverberar em seus textos, ao longo de toda sua obra, fornecendo, a seus leitores, subsídios teóricos de análise para seus próprios trabalhos. E foi nesse movimento, com essas próprias marcas deixadas no texto, que Luiz Fernando Carvalho parece ter encontrado suporte para a realização da minissérie Capitu, conciliado com seu singular modo reflexivo de demonstrar as coordenadas do fazer sincrético.

Todo processo estético, seja ele verbal ou sincrético, deve pressupor um olhar de fora do seu realizador. Um eu posicionado do lado de fora em relação ao outro, o que possibilita o objeto ser enformado de modo estético. A compreensão que fazemos da leitura de Carvalho transparece nos ressoos figurativos que ele tão bem trabalha por intermédio dos procedimentos de citação, seja de forma direta, seja de forma indireta. Esse ressoo de traços de significação, que nos remetem aos diálogos com outros textos e com outras tradições, configuram-se desde a escolha do cenário, o posicionamento da iluminação, os efeitos de enquadramento da câmera, a caracterização e o vestuário das personagens, até a trilha sonora escolhida para embalar a trama.

Há uma tomada de posição do diretor em sua recriação artística ao recuperar, mesclar e, ao mesmo tempo, atualizar os valores do tempo histórico do romance de Machado, século XIX, como do tempo de sua transposição, século XXI. Carvalho, ao realizar uma enunciação sobre outra enunciação, parece jogar com as possibilidades existentes de citação do romance dentro, agora, de um outro suporte. Assim, permite que o dialogismo presente no processo mostre-se de modo deliberadamente escancarado.

De acordo com Faraco (2009, p.61), Bakhtin reconhece o modo de percepção da dinâmica da criação dialógica ao constatar que a dialogicidade de todo dizer pode ser apreendida em três dimensões diferentes: "todo dizer não pode deixar de se orientar para o 'já dito'", ou seja, todo enunciado constitui-se como uma réplica e se configura a partir daquilo que chamamos de memória discursiva; "todo dizer é orientado para a resposta". Em outras palavras, todo enunciado espera uma réplica, sendo intrínseco ao enunciado o receptor presumido, qualquer que seja ele; como uma espécie de "auditório social", nos dizeres de Voloshinov, ou como um "superdestinatário", pelos 
dizeres de Bakhtin. Por fim, "todo dizer é internamente dialogizado", isto é, por ser heterogêneo, apresenta-se com uma articulação de múltiplas vozes sociais e como ponto de encontro e confronto dessas múltiplas vozes. Sua dialogização interna poderá ou não ser claramente mostrada, pois o dizer alheio pode vir, "[...] aspeado ou não, em escalas infinitas de graus de alteridade ou assimilação da palavra alheia". (FARACO, 2009, p. 60).

Seguindo essas três dimensões, verifica-se que o dizer da minissérie Capitu orienta-se não só pelo o que é dito no romance, ao preservar seu conteúdo, como também pelo que dele disseram os críticos. A resposta dada para o dizer do romance transposto configura-se como a compreensão ativa e crítica que Carvalho faz de todo esse processo, ora diluindo, ora espraiando, ora atualizando as possíveis leituras da obra, por um ponto de vista que carrega seu repertório, além da pesquisa do próprio repertório do escritor Machado de Assis. Por fim, temos o dizer internamente dialogizado no encontro desses dois enunciados (a leitura do romance e a leitura que Carvalho faz do romance) e que resultou numa realização artística repleta de vozes e discursos que são citados ora de modo mais explícito - aspeados, portanto - ora de modo mais implícito, sem aspas. Sendo assim, a compreensão do processo de transposição do romance verbal para a minissérie televisiva mostra-se por intermédio da exploração de variados procedimentos de citação que denunciam as leituras feitas do romance, da crítica e de supostos novos acréscimos pelo ponto de vista lançado pelo diretor.

Enquanto leitura artística e, portanto, seletiva, podemos perceber que Capitu trabalha o conteúdo do romance, tentando manter os diálogos, as personagens, as ações, deslocando, quase sempre e somente na expressão ${ }^{1}$, os diferentes sentidos atribuídos pela trama. Estão preservados não só as palavras e os diálogos, como também as divisões do texto em pequenos capítulos, através de cartelas/vinhetas que anunciam a cena que está por vir - "O penteado", "O agregado", etc.
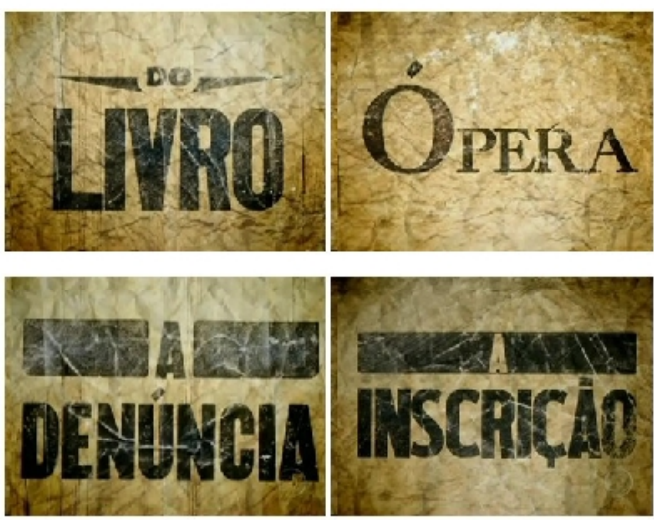

Figura 1 - Cartelas de abertura dos capítulos/episódios do DVD Capitu (2008)

\footnotetext{
${ }^{1}$ Quando se afirma, aqui, uma maior exploração evidente na expressão, não se está afirmando uma dissociação de seu conteúdo, pelo contrário. É somente por intermédio dele que conseguimos trabalhar com essas verificações com um texto que envolve diversas outras linguagens, destacando-se a visual
} 
O primeiro tratamento dado ao próprio texto de Machado não veio somente do olhar de Carvalho, mas de Euclides Marinho, seu colaborador na realização da minissérie, que produziu para o diretor um enorme levantamento dos trechos mais importantes da narrativa, criando determinadas ligações que guiavam a trama sem prejuízo em sua sequência. Sobre essa possibilidade de uma transposição, na íntegra, do conteúdo, Carvalho (2008, p. 77-78) afirma que

[...] o texto usado pelo elenco é absolutamente fiel ao que foi produzido por Machado. Fiz questão de ser bastante rigoroso neste ponto. $\mathrm{O}$ texto é Machado puro. Sem nenhum artigo meu, sem nenhuma vírgula minha. [...] O que eu fiz foi reafirmar o Machado em termos de conteúdo e linguagem. A síntese do texto é dele. É claro que eu espelhei aquelas situações e as lancei em outras relações de imagens, procurando um diálogo com possibilidades simbólicas da modernidade, abrindo o texto a outras visibilidades.

O que fica claro, para nós, é que Carvalho contou com a "ajuda", além da memória discursiva construída pelo leitor dos procedimentos de citação e referência textual, das visibilidades possíveis e permitidas pelo suporte televisivo. As citações, segmentadas em tipos como a paráfrase, paródia, alusão, estilização, citação "ipsis litteris" etc, podem aparecer manifestadas de várias maneiras em um texto literário e em um texto sincrético. Como uma obra parafrásica se denomina pela afirmação da ideia de outra obra, verificamos que Luiz Fernando Carvalho também se aproxima, por meio deste recurso, da ideia da bricolagem. Esta, para os semiólogos e os formalistas russos, é considerada uma "técnica de reescritura", uma substituição de um sistema que se banalizou e entrou em obsolência e que se encaixa também, por sua vez, na idéia de apropriação ${ }^{2}$ - termo que é recente na crítica literária, mas que chegou à nossa literatura por meio das artes plásticas, ou mais propriamente, do Dadaísmo.
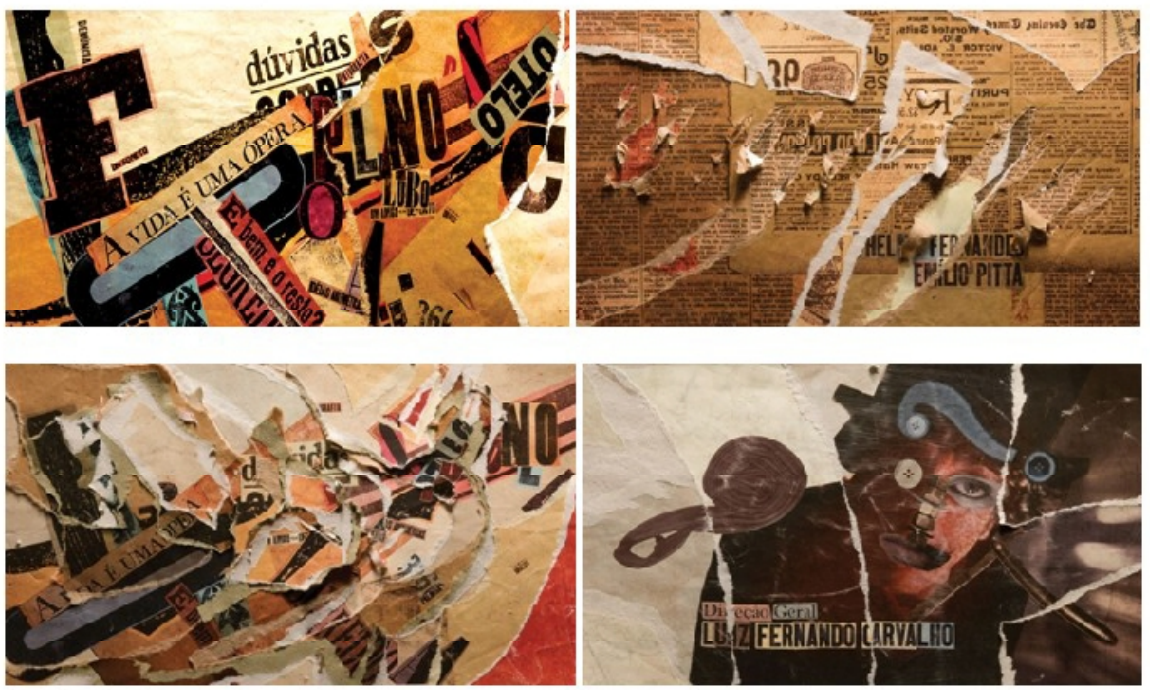

Figura 2 - Colagem/bricolagem da abertura da minissérie no DVD Capitu (2008)

\footnotetext{
${ }^{2}$ Affonso Romano de Sant'Anna (1985, p.43) define e exemplifica essa técnica de entrada recente na teoria da literatura: "A técnica da apropriação, modernamente, chegou à literatura através das artes plásticas. Principalmente pelas experiências dadaístas de 1916. [...]. Ela já existia nos ready-made de Marcel Duchamp, que consistia em apropriar-se de objetos produzidos pela indústria e expô-los em museus ou galerias, como se fossem objetos artísticos. Foi assim que ele tomou um urinol de louça, em 1917, e o expôs como obra de arte. [...]".
} 
De maneira sugestiva e quase didática, as técnicas de composição utilizadas nos quadros da abertura da minissérie figurativizam, por meio de um registro "ao vivo", o modo como uma pintura dadaísta era concebida. Cortando, sobrepondo, rasgando e/ou deslocando, palavras comuns do cotidiano são apresentadas com uma nova forma e dentro de um novo contexto. Aparentemente escolhidas ao acaso, as tiras de palavras reforçam o efeito recorrente de montagem que irá prevalecer durante toda a realização televisiva, além de dialogar com o modo experimental, proposto pelo Dadaísmo, tão valorizado pelo diretor Luiz Fernando Carvalho. A própria estruturação da transposição realizada pode ser considerada como uma bricolagem dadaísta.

Levando tal prática em consideração, podemos notar que a apropriação parafrásica consiste em apoderar-se de textos do outro e agir como se fosse do próprio autor, dilatando o sentido original, mas conservando sua essência. "Ao contrário da apropriação parodística, que inverte o significado ideológico e estético do texto, a apropriação parafrásica prolonga o texto anterior no texto atual", como afirma Sant'Anna em seu livro Párodia, Paráfrase e Cia. (1985, p.56). Essa apropriação prolongada pode ser verificada pela presença da reprodução de quase todos os capítulos do romance transpostos na minissérie, apresentando-os sem qualquer alteração no corpo do texto. Com essa preservação do texto original de Machado, o diretor parece propor uma nova visibilidade para a obra, por meio de recortes, ainda que possamos reconhecer uma espécie de respeito, homenagem, fidelidade e reconhecimento com o trabalho do escritor. Ao reproduzir e respeitar o conteúdo manifestado de Dom Casmurro, Carvalho acabou por reproduzir, na minissérie, uma unidade discursiva semanticamente equivalente à produzida anteriormente pelo romance.

Como podemos observar, embora sejam perceptíveis as alterações em sua forma primária, a paráfrase realizada na transposição do romance para a televisão instaura uma relação de identidade com o conteúdo expressado. Seguindo a definição de paráfrase proposta por Greimas, em Semiótica e ciências sociais (1981), podemos conceber sua existência dividida em dois tipos: 1) Paráfrases substitutivas (ou denotativas), que visam à equivalência direta com o enunciado parafraseado; 2) Paráfrases oblíquas (parcialmente conotativas), cujo conteúdo não torna ambíguo o enunciado primeiro.

Em relação ao romance machadiano, é possível afirmar que Carvalho conserva a mesma estrutura fundamental do texto parafraseado. Contudo, o modo privilegiado para parafrasear certas passagens é feito por meio da exacerbação de traços caricaturescos, que, no texto de partida, já se faziam notáveis pelo tom grandiloquente e operístico diluído por Machado, mas amplamente explorado pelo diretor Carvalho, já que este parece estilizar tudo o que pode na transposição. Há, desse modo, um sentido inverso criado: Machado, sutil, é lido, por um Carvalho nada sutil, posto que escancarado. Dessa forma, podemos classificar as reproduções encontradas na realização como exemplos de "paráfrase oblíqua", justamente por não prejudicarem o conteúdo a que se vinculam, embora este se mostre obliquamente reproduzido. 
Em Capitu, há, notoriamente, uma mediação com o livro e uma mediação com a sociedade. Como numa tríade, temos o retrato do Rio de Janeiro do século XIX, o romance ancorado nesse Rio de Janeiro de 1857 e, por fim, a minissérie que transpõe esses dados para um tratamento atemporal, marcado por uma leitura contemporânea dos fatos. A mediação entre essas esferas de circulação e produção apresentam-se na realização final de Carvalho por este optar em mesclar, por exemplo, figurinos tidos de época, com uma musicalidade altamente moderna e até mesmo de cultura pop, evidenciando a questão das diferentes e, ao mesmo tempo, análogas sincronias.
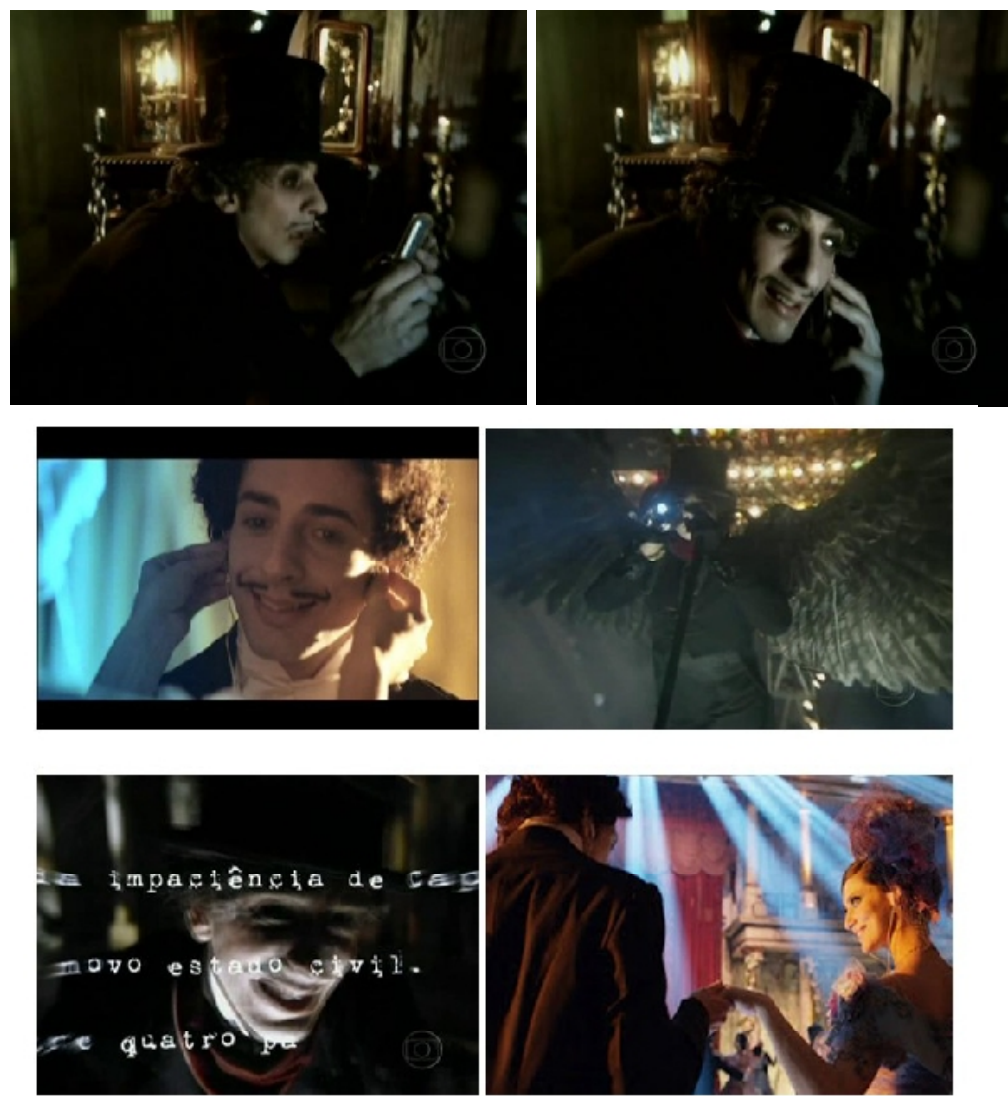

Figura 3 - A alternância nos tempos pelo uso de objetos contemporâneos no DVD Capitu (2008)

Observamos um Bentinho que usa celular, dança valsa com um ipod, grava sua história com uma filmadora de alta definição e escreve sua história ora com tinta e pena, ora com os recursos próprios de um blog online. Dessa forma, o jogo criado com objetos valorizados por épocas distintas reforça o efeito de atemporalidade da obra, engendrando no telespectador um reconhecimento da eficácia narrativa de Machado até mesmo em tempos modernos.

Como ainda afirma Greimas (1981, p. 325), o procedimento de paráfrase deve ser concebido como um dos dois modos existentes de produção e de reconhecimento da própria significação, "[...] mais precisamente, como o modo paradigmático, em 
oposição ao sintagmático, que consistiria na sua apreensão enquanto intencionalidade". Além de ser um efeito retórico e estilístico, a paráfrase apresenta ainda um caráter ideológico de continuidade de um pensamento, fé ou procedimento estético. A estilização, por sua vez, segundo as considerações de Bakhtin (1981), trabalha o texto sob o ponto de vista do outro, ainda que seu próprio ponto de vista seja perceptível, pela maneira objetiva pela qual é retratada. Assim como na paráfrase, na estilização, ocorre uma captação do sentido do texto original. Em outras palavras, com ambos os recursos há uma captação dos níveis fundamental, narrativo e discursivo dos textos-base, pois, como diz Norma Discini (2001, p.66), "[...] usar o discurso de um outro como o discurso de um outro é captar-lhe as estruturas fundamentais, narrativas e discursivas."

Além do reaproveitamento de todos os níveis da geração de sentido, a estilização, como o próprio nome induz, estiliza o texto, acrescentando-lhe cores, figuras, tons, personagens e diálogos, sem perder a estrutura básica que compõe o conteúdo inicial do texto anterior a que se refere. Ela se mostra como uma imitação de um texto ou estilo, sem a intenção de negar, ridicularizar ou desqualificar o que está sendo imitado. Na estilização, ao contrário do que ocorre na paródia, as vozes são convergentes na direção do sentido, pois as duas apresentam a mesma posição significante, conforme lembra Fiorin (2006).

Pode-se verificar, até mesmo na exuberância do acabamento visual da minissérie Capitu, a presença de um trato inchado com o visual na exploração de suas cores, na construção de traços figurativos que remetem às leituras feitas por Carvalho e no exagero do tom dado pelas falas das personagens que são trabalhadas de modo caricatural e expressionista. Luiz Fernando, assim, carrega na tinta em sua transposição, enquanto que Machado era justamente ao contrário: sutil, leve, ainda que com ironia cruel, fina. Na minissérie, as imagens dominam a cena em detrimento do universo narrativo do romance; e é justamente esse movimento que se espera da televisão e do cinema quando trabalham com uma transposição de obra literária. A constante utilização de cores vivas, favorecidas pelo uso da tecnologia digital em alta definição, configura uma nova estética para um romance publicado no século XIX.
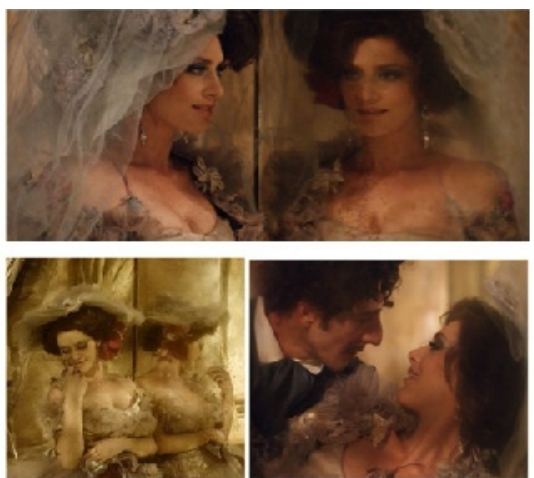

Figura 4 - O acabamento visual da minissérie - Fonte: DVD Capitu (2008) 
Tais acréscimos acabam, portanto, por tornarem diferentes, visualmente, a realização televisiva do discurso presente no texto de Machado de Assis. Sant'Anna (1985) declara que, assim como a paráfrase conforma, a estilização reforma. Essa captação criativa "carvalhiana", que ocorre por meio da estilização, resulta numa relação de causa e efeito de alterações no conteúdo manifestado no discurso. Assim, "o texto-base recriado fica, também, ideologicamente confirmado, ainda que uma leve sombra recaia sobre ele". (DISCINI, 2001, p.72-73).

Em nossa leitura, gradativamente, inferimos que Carvalho estiliza não o texto machadiano, e sim seu processo de criação e trato com o romance, uma vez que Machado, com sua sutileza marcante, parece dizer tudo, sem dizer nada. Há, assim, uma estilização não do texto transposto, mas das técnicas usadas para sua transposição. Temos, desse modo, um diretor lendo, com os recursos do procedimento da estilização, um romance que tudo sugere, entretanto, no fim, é a minissérie que escancara.

A paráfrase apesar de apropriar-se integralmente do texto no qual se espelha, constrói-se de maneira tortuosa, ou seja, não segue uma linha reta de captação das semelhanças e até das diferenças que resultaram no texto final. Em razão disso, podese justificar, na minissérie, a escolha por certas omissões de capítulos da obra, bem como fusões de outros pelo diretor. Tais omissões podem, inclusive, passar despercebidas para um telespectador que não tenha comparado a sequência que o livro estabelece com seus capítulos com as vinhetas de abertura que desempenham essa mesma função de abertura de quadros para a história.
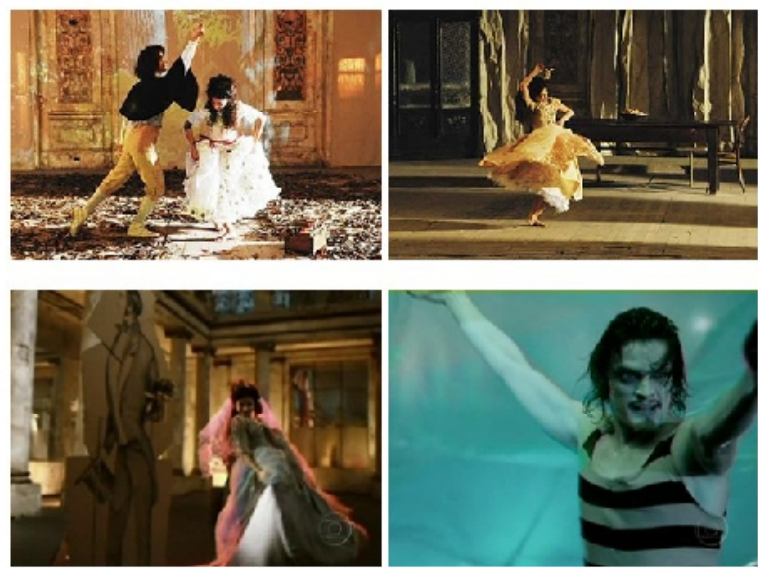

Figura 5 - A gestualidade teatral das personagens - Fonte: DVD Capitu (2008)

Seus cenários, figurinos e objetos de cena, confeccionados artesanalmente, compõem uma mescla entre o erudito e o popular, a qual dialoga com o próprio retrato que Machado fazia de tais esferas em seus romances. Os amplos movimentos da câmera em torno das personagens evidenciam a intensa busca por uma expressão corporal que se aproxime (e muito) da teatralidade tão presente nas obras de Machado. A escolha dos enquadramentos parece obedecer aos movimentos musicais e coreográficos dos atores ao apresentarem um ritmo em conjunção aos apelos dramáticos presentes na narrativa. E, quando obedecem, exagera-se no tom, 
escancarado pelo modo de falar e de se posicionar das personagens, criando um efeito de teatralidade deliberado.

Todas as personagens de Capitu valorizam seus movimentos em cena como se estivessem em uma peça teatral e/ou um espetáculo de dança coreografada. Evidenciando o caráter de representação escancarado, suas gestualidades criam um novo ritmo para o narrar televisivo. O que se pode ter, portanto, como definição da paráfrase feita com o romance de Machado é sua possibilidade - enquanto procedimento citativo de um dizer orientado - de apresentar-se como ornamentação do texto original, uma vez que a paráfrase acaba "inchando mais o seu discurso, ou para sermos mais gentis, fazendo sonhar mais" (DISCINI, 2001, p.211). Assim como a estilização, a paráfrase modifica o texto, embora, muitas vezes, de maneira imperceptível, pois se policia a somente modificar e acrescentar certos detalhes em seu plano de expressão. Para tal efeito, utiliza-se de figuras como a hipérbole, por exemplo, ao maximizar elementos ou situações.

Tanto a paráfrase quanto a estilização permitem o desenvolvimento de certa liberdade de criação de um texto segundo ao recriarem, estilizarem, inventarem ou apenas mudarem alguns elementos de lugar. Carvalho parece ter conseguido transpor não só o romance, mas as demais leituras com as quais o próprio romance dialoga em sua configuração imagética. Tal efeito é conseguido por intermédio do processo de figurativização que se mostra, principalmente, atravessado pelo recurso da estilização, visto que este, para captar fundamentalmente o texto-base, precisa encontrar outros meios para reproduzi-lo. Essas outras possibilidades de reprodução são alicerçadas pelo uso de metáforas e alegorias que transformam o texto-base, ampliando o seu alcance, universalizando seus temas e figuras e fazendo com que em seu discurso ecoe uma liberdade e criatividade dialógica.

Luiz Fernando Carvalho, portanto, apropria-se tanto da paráfrase, quanto da estilização3 como principais meios de citação para a transposição do dizer do outro, no caso, do dizer do romance de Machado e de seu próprio repertório. Tais procedimentos transparecem na aproximação televisiva por ambos manterem, entre si, uma relação de conformidade com o texto-base e se relacionarem por meio da atuação de complementaridade um do outro. Diferencia-se a paráfrase pela atitude mais dependente do texto-base, ao passo que a estilização possibilita, para o realizador, alçar certa independência ao desenvolver e alterar os elementos do texto primeiro e suas possíveis combinações de sentido.

Encontramos, além disso, na aproximação televisiva, alguns deslocamentos de reprodução que podem até ocasionar certa deformação semântica (sem comprometer totalmente o conteúdo), ocorrendo, - não como na paródia que nega totalmente o sentido -, uma mudança de enfoque da narrativa primeira. Tal procedimento pode ser verificado no deslocamento que ocorre no próprio título escolhido para a minissérie, Capitu. Em uma primeira leitura, parece que a ênfase é dada à enigmática e oblíqua personagem, mas, analogamente ao romance, a minissérie é lida, interpretada, vista e exibida pelos olhos de uma câmera quase que embutida nos pensamentos e devaneios do narrador protagonista Casmurro.

\footnotetext{
${ }^{3}$ É importante frisarmos, contudo, que a estilização é encontrada no processo de leitura realizado
} por Carvalho e não no texto de Machado. 


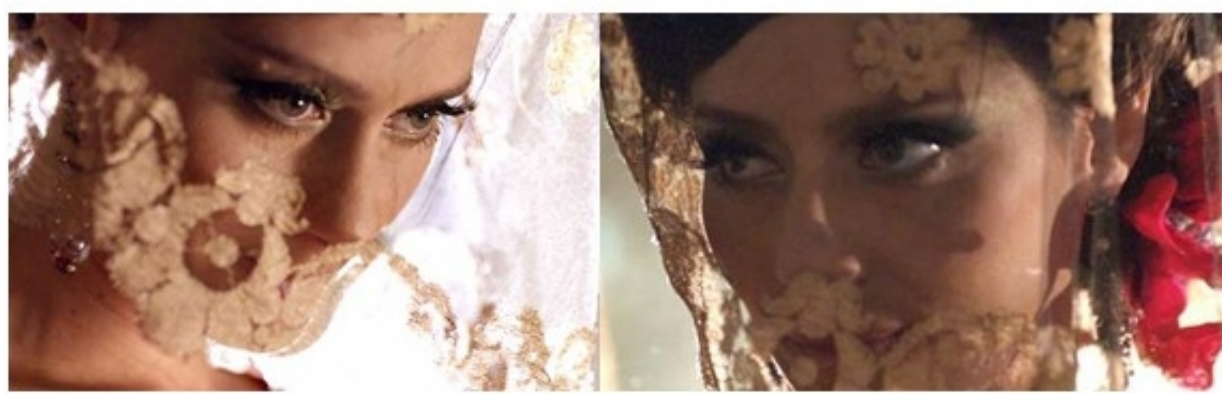

Figura 6 - A fixação de Bentinho (e, consequentemente, da câmera) pelos olhos de Capitu no DVD Capitu (2008)

Não há, portanto, uma deformação, e sim apenas um deslocamento na criação de efeito de sentido ao demonstrar, com tal desvio no nome, não importar de quem parte o contar dessa narrativa, pois o que temos, em termos de conteúdo de relato, são somente as impressões já consolidadas pela fala de Bentinho. Capitu, aqui, como representante de um capítu(lo) à parte sobre o modo como tudo, sempre, vem a ser uma questão de ponto de vista, de como se lê algo. O título, inclusive, é propício para a definição de enveredamento aos estudos sincréticos: é pelo ponto de vista do enunciador que temos que pensar e analisar nosso objeto. Carvalho (2008, p. 82) declara:

Em Capitu, não há uma única palavra ou vírgula que não seja de Machado. Logo, o Enigma permanece. Por isso também optei por outro título, Capitu, onde a idéia de uma tentativa de aproximação com o romance Dom Casmurro ficaria ainda mais clara, revelando não se tratar apenas de uma transposição de um suporte para outro, mas sim de um diálogo com a obra original.

O espaço escolhido para ser o cenário de toda trama também se desvia do sentido posto no livro por não mobilizar as diversas ruas citadas no romance, mas optar por fixar-se em um único espaço, construído com os valores de nossa sociedade atual. É dentro do Automóvel Club do Brasil, situado e fundado nos anos 70, no Rio de Janeiro, que Carvalho transpôs e construiu, como um espaço da memória do narrador Dom Casmurro, todos os capítulos da trama. A opção por centrar a locação de suas realizações anteriores, também em um único espaço, cria um efeito de sentido de teatralidade, uma vez que seja em Hoje é dia de Maria, seja em A Pedra do Reino, seja em Capitu, há um único palco para a trama ser desenvolvida e apresentada para o público/telespectador.

A paráfrase, embora tenha alguma relação com 0 fenômeno da "correspondência" proposto por Mário Perini (1995), apresenta um deslocamento que é classificado como mínimo, por utilizar a técnica de citação e transcriação direta do texto-base. Já na estilização, essa noção de deslocamento aumenta, por ser justamente uma afirmação do contrário. Nesse sentido, o que verificamos em Capitu em relação a Dom Casmurro é a ocorrência de um jogo de diferenciação, pelas próprias escolhas e combinações do ponto de vista do leitor que Carvalho se mostra, no que concerne ao texto original, mas sem que ocorra uma mutilação ao significado primeiro, ao plano de conteúdo da obra machadiana. 
Esse processo de deslocamento implica a classificação da noção de desvio, que acontece em cada um desses recursos. Para estabelecermos o grau de alteração que a paráfrase e a estilização produzem, precisamos levar em conta as relações que existem entre o texto segundo e o texto-base. Geralmente, a paráfrase se apresenta com um desvio mínimo de conteúdo, enquanto a estilização, um desvio tolerante. Essa tolerância, comportada somente pela estilização, consiste no grau máximo que um texto pode assumir de inovação na expressão, sem que the mude o sentido ou altere seu paradigma inicial.

Assim, Sant'Anna (1985, p.28) considera a paráfrase como um eixo sintagmático, parafrásico, que, ao repousar "[...] sobre o idêntico e o semelhante, pouco faz evoluir a linguagem. Ela se oculta atrás de algo já estabelecido, de um velho paradigma". Nesse sentido, o velho paradigma se mostra presente no dizer reproduzido do romance nos diálogos transpostos e respeitados pelos autores da aproximação. Contudo, o que se mostrou de modo diferenciado, muitas vezes, na transposição dos mesmos diálogos para a minissérie, foi a entonação dada para determinadas palavras que demonstravam, em consequência, carregar consigo outros sentidos mais latentes. Além da entonação dos diálogos, o próprio tom burlesco, operístico e barroco, nos adornos e nas expressões escolhidas por Carvalho, criou uma entonação própria para a realização, definida por sua relação com o objeto do enunciado, o romance, e com os enunciados dos outros que reverberam no ato de sua criação estética. Como um exemplo visual e sonoro de entonação expressiva, partindo da sutileza da palavra para o exagero visual, podemos contrastar a aparição da personagem Escobar no texto verbal e no texto sincrético. No romance, conforme mostramos abaixo, há a descrição de seu caráter misterioso e fugidio por meio da observação dos seus gestos corporais.

Eis aqui outro seminarista. Chamava-se Ezequiel de Sousa Escobar. Era um rapaz esbelto, olhos claros, um pouco fugitivos, como as mãos, como os pés, como a fala, como tudo. Quem não estivesse acostumado com ele podia acaso sentir-se mal, não sabendo por onde lhe pegasse. Não fitava de rosto, não falava claro nem seguido; as mãos não apertavam as outras, nem se deixavam apertar delas, por que os dedos, sendo delgados e curtos, quando a gente cuidava tê-los entre os seus, já não tinha nada. O mesmo digo dos pés, que de tão depressa estavam aqui como lá. Esta dificuldade em pousar foi o maior obstáculo que achou para tomar os costumes do seminário. O sorriso era instantâneo, mas também ria folgado e largo. Uma cousa não seria tão fugitiva, como o resto, a reflexão; íamos dar com ele, muita vez, olhos enfiados em si, cogitando. Respondia-nos sempre que meditava algum ponto espiritual, ou então que recordava a lição da véspera. Quando ele entrou na minha intimidade pedia-me freqüentemente explicações e repetições miúdas, e tinha memória para guardá-las todas, até as palavras. Talvez esta faculdade prejudicasse alguma outra. (ASSIS, 2008, p. 208)

Já na minissérie, tais descrições dos gestos corporais ganham ênfase de rebeldia e de morbidez. Ao som instrumental do heavy metal "Iron Man", da banda inglesa Black Sabbath (1968-), Escobar entra em cena. Chocando e/ou chamando atenção por onde passa, a personagem sobe na mesa de seus colegas seminaristas e dirige, 
enfaticamente, o olhar para a personagem Bentinho, que se mostra em estática admiração. O predomínio da cor preta em cena, ofuscada, em muitos momentos, por uma luminosidade clara, engendra um efeito de dubiedade do caráter deste personagem.
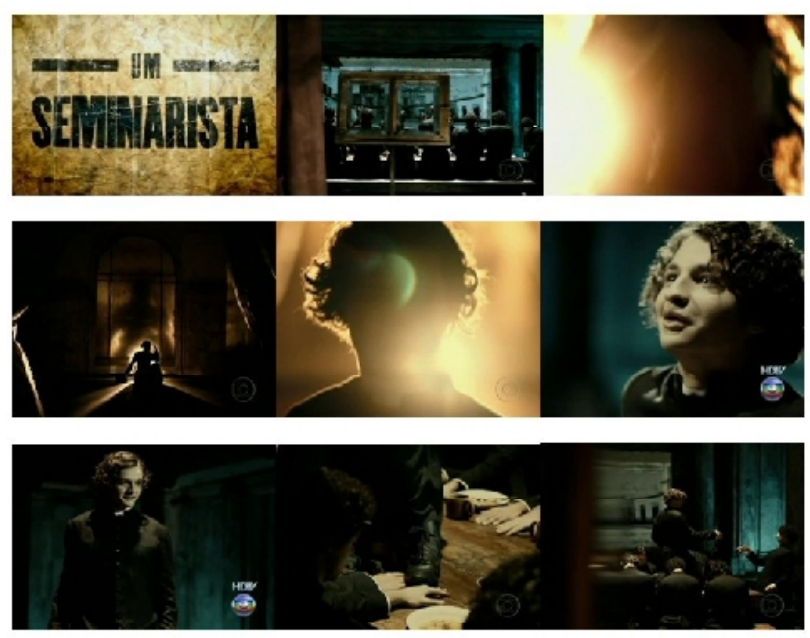

Figura 7 - Plano-sequência correspondente ao Capítulo LVI "Um seminarista" do DVD Capitu (2008)

Ainda, essa aparição com contornos profanos e sagrados remete ao peso da tradição que tal personagem carrega por ser o principal "suspeito" de todo o desenrolar do nunca confirmado adultério. Escobar, assim, ganha o tom pesado que tão bem lhe cabe, uma vez que Dom Casmurro o carrega em sua mente atormentada e, não menos, pesada. Em outras sequências, teremos, ainda, o andar e os gestos de Escobar acentuadamente teatrais. Seus olhos azuis e furtivos, também como o mar, ganham repetidos closes na captação de imagens ao longo da realização.
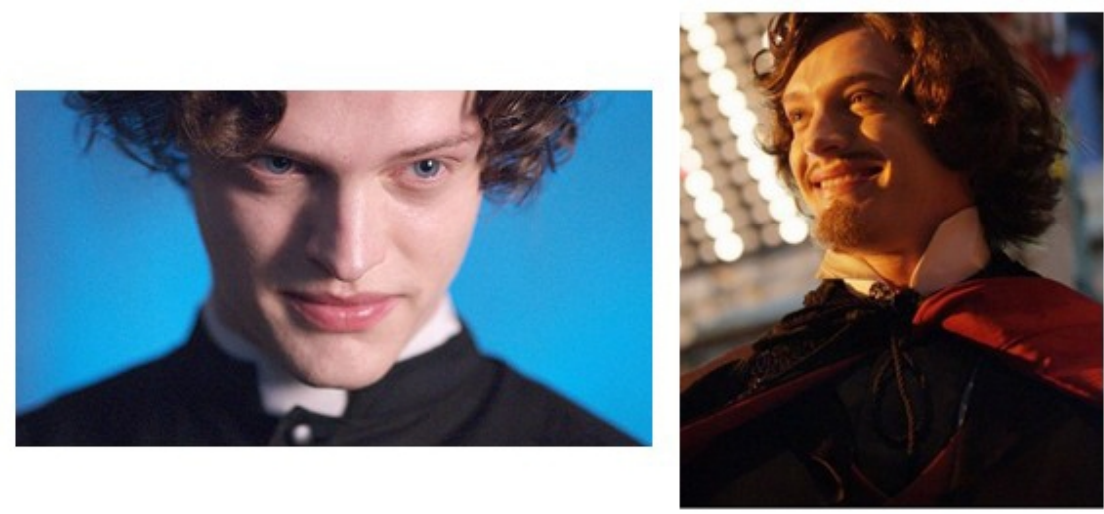

Figura 8 - Os olhos azuis e furtivos de Escobar no DVD Capitu (2008)

Bakhtin, em seu texto "Os gêneros do discurso" (1992, p. 311), esclarece essa valoração que cada palavra adquire quando tratada por uma entonação expressiva e carregada de valores de outros enunciados. 
Ao escolher a palavra, partimos das intenções que presidem ao todo do nosso enunciado, e expressividade (ou melhor, nossa expressividade) para cada uma das palavras que escolhemos e que, de certo modo, inocula nessa palavra a expressividade do todo. Escolhemos a palavra de acordo com sua significação que, por si só, não é expressiva e pode ou não corresponder ao nosso objetivo expressivo em relação com as outras palavras, isto é, em relação com o todo do enunciado. A significação neutra de uma palavra, relacionada com uma realidade efetiva, nas condições reais de uma comunicação verbal, sempre prova o lampejo da expressividade. [...] apenas o contato entre a significação lingüística e a realidade concreta, apenas o contato entre a língua e a realidade - que se dá no enunciado - provoca o lampejo da expressividade. Esta não está no sistema da língua e tampouco na realidade objetiva que existe fora de nós.

Esse lampejo da expressividade, portanto, mostra-se no ato carregado de fala e de gestualidade das personagens da minissérie ao espelhar os outros valores que cada personagem pode representar na narrativa, bem como corrobora a manutenção do diálogo existente entre a obra machadiana e o teatro, a ópera e a música. Esse diálogo com outras artes pode ser notado, ainda, nos enquadramentos dados à expressividade da personagem Dom Casmurro.

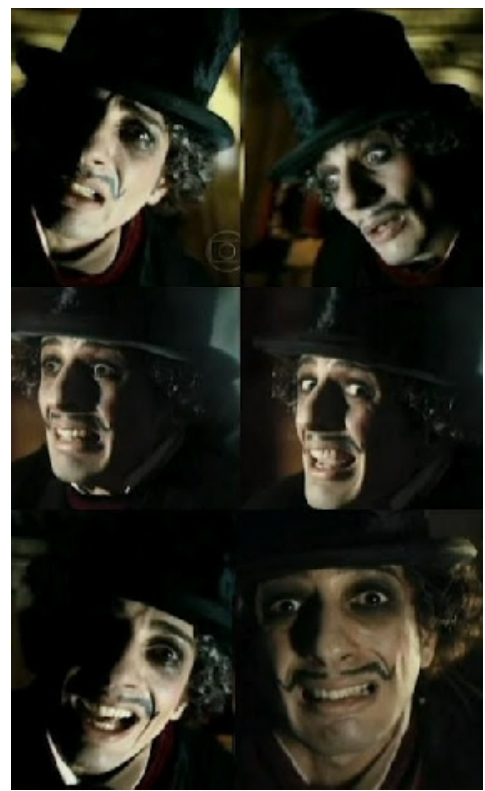

Figura 9 - A entonação expressiva do narrador Dom Casmurro no DVD Capitu (2008)

Misturando melancolia com galhofa, sua caracterização alternada cria um efeito ora grotesco, ora cômico. Essa nova entonação dada corrobora a isotopia de leitura estabelecida: a recuperação de vários olhares, na expressão, resultantes da diversidade de interpretações existentes sobre o romance. A nossa leitura é a de que Carvalho, por meio dos procedimentos discursivos de citação, tentou recuperar o que é comum da leitura geral sobre a composição das personagens, estilizando e valorizando, a seu modo, a entonação expressiva de cada um.

Podemos, ainda, interpretar a paráfrase por dois caminhos: o linguístico, ligado às formas e à estrutura que se mantêm ou se alteram; ou o caminho aberto, que possibilita diversas interpretações e, por conseguinte, é mais livre e nele podemos 
reconhecer todo o trabalho dessa linguagem poética, criativa e inovadora. Esse segundo caminho de interpretação sobre a paráfrase a aproxima da estilização, permitindo-nos afirmar, novamente, que, no corpus em questão, as duas caminharam juntas no processo de construção, complementando uma à outra. A paráfrase realizada pelo diretor Carvalho poderia ser entendida como uma espécie de estilização positiva, considerando que o termo "positivo" indica uma aproximação maior em relação ao texto original.

Em um texto, os desvios que ocorrem em relação às ideias originais podem caminhar em duas direções, uma positiva e outra negativa. A estilização, juntamente com a paráfrase, em nosso texto-objeto, caminhou na mesma direção ideológica que o romance propõe. Contudo, tal trajeto se deu de modo atualizado em relação aos valores expressos pelo romance, ao reproduzir uma história ancorada no século XXI, tratando de um tema universal e com recursos altamente tecnológicos para sua reprodução.

É próprio do gênero romance pôr em cena o conflito discursivo que se trava em um determinado momento, em uma dada formação social, favorecendo, assim, a expressão do dialogismo - em seu mais alto grau - devido à exploração, com maior destaque, da diversidade, da diferença e da heteroglossia das vozes configuradas num relato. Na minissérie de Carvalho, isso não se mostra de modo diferente. As vozes sociais que figuram numa sociedade altamente tecnológica do século XXI reverberam no discurso da minissérie, não só pelo constante uso de objetos tecnológicos mesclados aos objetos artesanais componentes do cenário, bem como na ênfase dada em alguns temas tratados de forma sutil já no romance do século XIX, mas que, atualmente, ainda se encontram em voga em diversas discussões da crítica moderna.
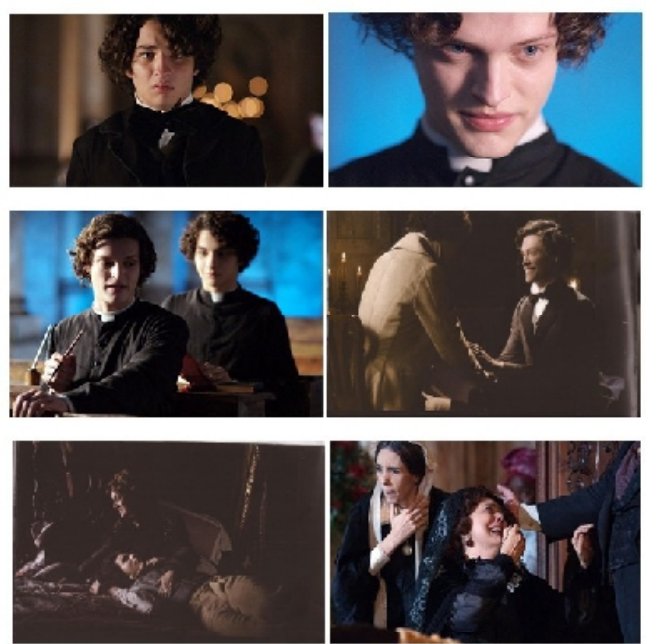

Figura 10 - A ênfase dada em alguns temas trabalhados de modo sutil pelo romance Fonte: DVD Capitu (2008)

Indícios que antes eram apenas sugeridos e trabalhados, sutilmente, pelo texto do romance machadiano, ganham destaque devido ao tom dado na minissérie. Uma possível relação incestuosa entre a mãe Dona Glória e seu filho Bentinho ganha 
contornos mais visíveis; uma certa relação homoafetiva ou, até mesmo, homossexual, entre Escobar e Bento parece irromper nos gestos e olhares das personagens; uma infantilização da personagem Bento Santiago avoluma-se em comparação à sensualidade determinada de Capitu. E estes são apenas alguns dos acréscimos de interpretação que dialogam com as recentes leituras sobre a obra Dom Casmurro.

Embora tais desvios evidenciados pelo tom estilizado engendrem outras possibilidades de leitura, verificamos que a temática e a composição que caracterizam - romance Dom Casmurro foram preservados na transposição televisiva. Essa manutenção estrutural, que enquadra a obra dentro do gênero romance, pela minissérie, facilita o reconhecimento dos índices identificadores do próprio gênero primeiro de que partiu o enunciado televisivo. O caminho contrário, realizado quando a estilização caminha numa direção diferente do texto-base, estiliza uma paródia. Esse caminho confirma a hipótese da estilização como um efeito geral que pode ser aplicado tanto com a paráfrase quanto com a paródia; o que as diferencia é a maneira como cada autor vai trabalhar e explorar seus recursos. O efeito geral construído pela paráfrase e pela estilização consiste em uma alteração na estrutura linguística ou uma simples correspondência de formas sintáticas. Em Capitu, pelo trato autoral dado aos dois procedimentos de citação, verificamos, também, um certo grau de liberdade e autonomia para o diretor que pode, assim, ter uma história em mãos, mas manuseála, pelos recursos do audiovisual, de modo diferenciado.

Mais do que isso, porém, é preciso reconhecer e analisar, a relação e os efeitos de sentido que esses procedimentos discursivos de citações, ao serem explorados por determinados textos, estabelecem entre o enunciador, com seus valores lançados no texto, e o enunciatário, com sua recepção e interpretação que são alçados, por sua vez, por outros valores. Conforme nos lembra Faraco (2009, p. 22),

O eu e o outro são, cada um, um universo de valores. O mesmo mundo, quando correlacionado comigo ou com o outro, recebe valorações diferentes, é determinado por diferentes quadros axiológicos. E essas diferenças são arquitetonicamente ativas, no sentido de que são constitutivas dos nossos atos (inclusive de nossos enunciados): é na contraposição de valores que os atos concretos se realizam; é no plano dessa contraposição axiológica (é no plano da alteridade, portanto) que cada um orienta seus atos.

Para se estabelecer uma relação parafrásica e/ou estilizada com outro texto, é preciso considerar a maneira como o receptor dessa mensagem vai receber esse código e, então, captar e reconhecer os valores presentes e mobilizados por aquele enunciado atravessado por outros valores. Se o leitor não tem informação do texto original ou de outras relações com as quais o texto mantém possíveis diálogos, não vai conseguir identificar essas figuras e seus respectivos efeitos. "É preciso um repertório ou memória cultural e literária para decodificar os textos superpostos" (SANT'ANNA, 1985, p.26), pois os traços, as figuras e os objetos do mundo natural passam a ser transformados, substituindo seus significantes originais por outros.

É importante ressaltar, no entanto, que o não reconhecimento dos diálogos estabelecidos pelo texto não invalida a recepção da obra por um leitor que não se aprofunde no reconhecimento das relações citadas e no modo como elas trabalharam o 
repertório tanto do leitor Machado, quanto do leitor Carvalho. Contudo, desconstruir e estudar o processo de leitura e criação figurativas, realizadas por uma transposição de uma obra literária para um meio sincrético, favorece o entendimento das relações existentes entre literatura e televisão, literatura e cinema, fornecendo, inclusive, métodos de análises que ainda estão em constante verificação por congregar duas linguagens tão diferentes, mas com tantos pontos de convergência. Além disso, percorrer o universo machadiano pelo ponto de vista que o diretor Carvalho imprimiu em sua realização estabelece uma relação de compreensão dialógica, responsiva e figurativa, enquanto leitores/telespectadores de um texto tão içado de relações, alusões, leituras e repertórios como Dom Casmurro, contudo visto, agora, sob a lente da câmera de Capitu.

A própria literatura de Machado, com todo um diálogo alçado na tradição, parecer ter fornecido material teórico e analítico para Carvalho aproximar-se, criticamente, do romance machadiano que, até hoje, causa estranhamento, desconfianças, afirmações e, principalmente, possibilidades de diálogos. Ainda que sem refutar ou sem confirmar, explícita e integralmente, nenhuma das leituras expostas, o enunciador sincrético parece recolher o que cada uma pôde contribuir para uma nova configuração da obra. Desse modo, essa configuração se mostra construída por intermédio da exploração de leituras e citações que ressoam, principalmente, na exploração do plano da expressão que o gênero minissérie permite por suas próprias características. Esse movimento dá a ver um processo de transposição que privilegia a manutenção do conteúdo da obra transposta. No entanto, trabalha, principalmente, com a exploração das escolhas evocadas pelas outras enunciações mobilizadas por um gênero que sincretiza diversas outras linguagens, pensadas como uma estratégia global enunciativa responsável pela continuidade discursiva resultante da textualização em questão.

\section{Referências}

ASSIS, M. de. Dom Casmurro. Apres. de Paulo Franchetti e notas de Leila Guenther. Cotia: SP; Ateliê Editorial, 2008.

BAKHTIN, M. Problemas da obra de Dostoiévski. Trad. de Paulo Bezerra. Rio de Janeiro: Forense, 1981.

Os gêneros do discurso. In: Estética da criação verbal. Trad. do francês por Maria Ermantina Galvão; Rev. de Marina Appenzeller. 3 ed. São Paulo: Martins Fontes, 1992, p. 279-287.

CARVALHO, L.F. Diálogo com o diretor. In: Capitu. Rio de Janeiro: Casa da Palavra, 2008, p.75-83.

DISCINI, N. Intertextualidade e conto maravilhoso. São Paulo: Humanitas-FFLCHUSP, 2001. 
FARACO, C. A. Linguagem \& diálogo: as ideias linguísticas do círculo de Bakhtin. Curitiba: Criar, 2009.

FISH, S. Is there a text in this class? The authority of interpretive communities. Cambridge, Massachussets \& London: Harvard University Press, 1980.

FIORIN, J. L. Introdução ao pensamento de Bakhtin. São Paulo: Ática, 2006. GREIMAS, A. J. Semiótica e ciências sociais. São Paulo: Cultrix, 1981.

SANT'ANNA, A. R. de. Paródia, Paráfrase \& Cia. São Paulo: Ática, 1985.

Title: The dialogical reading work in a transposition from a verbal text to a syncretic one

Abstract: The possibility of a detailed study about the creative process of a TV miniseries, based on the transposition of a literary work, instigated us to want to comprehend better the relations that exist between literature and film, literature and television, specially after the work of director Luiz Fernando Carvalho adapting Machado de Assis's novel Dom Casmurro (1899) to the miniseries Capitu (2008). The understanding of Carvalho's reading becomes visible in the figurative resoundings he puts into evidence through procedures of citation, be it in direct form, be it in indirect form. This resounding of traces of meaning, that links to dialogues with other texts and with other traditions, is configured from the choosing of the stage setting, positioning of lighting, effects of camera framing, the characterization and clothing of the characters, to the musical score chosen to create rhythm in the plot, thus filling and updating Dom Casmurro to new visibilities, dialogues and interpretations.

Keywords: Transposition. Machado de Assis. Discursive procedures of citation. Luiz Fernando Carvalho.

Recebido em: 12/08/2013. Aceito em 30/11/2013. 